\title{
ŚMIERĆ WEDŁUG PRAWA W STAROŻYTNYM EGIPCIE I W PRAWIE ŻYDOWSKIM ${ }^{1}$
}

Śmierć, jako naturalne zakończenie życia człowieka, była różnie postrzegana w różnych kulturach prawnych na przestrzeni wieków. Według kultur pierwotnych Afryki naturalny cykl życia człowieka nie przewidywał śmierci z przyczyn naturalnych. Zawsze ktoś lub coś ponosił winę za śmierć człowieka. Starożytni rzymianie dostrzegali różnicę pomiędzy nagłym zgonem człowieka wywołanym przyczyną zewnętrzną a naturalną śmiercią człowieka. Rozróżniali także różne zasady odpowiedzialności prawnej w przypadku gdy życie ludzkie uległo zakończeniu w wyniku działania czynników zewnętrznych, głównie w zależności od tego do jakiej grupy społecznej należała ofiara. Prawo do naturalnej śmierci lub inaczej prawo do życia postrzegane było odmiennie w różnych kulturach prawnych. Warto zatem przyjrzeć się jak kształtowało się ono w staroży tnym Egipcie i równolegle w powiązanym $\mathrm{z}$ nim prawem żydowskim. Istotne jest bowiem ustalenie kiedy w naszym kręgu kulturowym pojawiło się rozróżnienie pomiędzy śmiercią z przyczyn naturalnych a śmiercią w świetle prawa. Różne podejście do samego faktu śmierci w kontekście uprawnienia człowieka do odebrania życia drugiemu jest bowiem obecne w obu tych kulturach prawnych. Istnieją także elementy im wspólne. Współcześnie przyjmuje się iż każdemu człowiekowi przypisane jest prawo do życia, a co za tym idzie do naturalnej śmierci. Niektóre systemy prawne roszczą sobie jednak prawo do decydowania o życiu człowieka w sytuacji gdy popełnił on przestępstwo, które w ocenie danego ustawodawcy kwalifikuje sprawcę do wyeliminowania go na stałe ze społeczeństwa. Kultura starożytnego Egiptu także zawierała normy prawne, które pozwalały na zgodne z prawem odebranie życia drugiemu człowiekowi.

\footnotetext{
* DR MAGDALENA BUTRYMOWICZ - radca prawny, asystent na Wydziale Nauk Społecznych Uniwersytetu Papieskiego Jana Pawła II w Krakowie.

1 Artykuł powstał w czasie badań naukowych przeprowadzanych w British Muzeum w Londynie, Wydział Egiptologii i starożytnego Sudanu.
} 


\section{1. Śmierć człowieka według Egipcjan}

Według starożytnych Egipcjan „zmarły” to ten, który pośredniczy, ten który leczy, ale także ten, który został przeklęty na sądzie po śmierci ${ }^{2}$. Śmierć w starożytnym Egipcie postrzegana była zatem jako pewien proces, do którego należało się przygotować. Zmarły powinien być pochowany w bogato zdobionym grobie, który powinien trwać przez wieki. Mężczyzna zazwyczaj był chowany w głównej części grobowca ze swoimi żonami a czasami z innymi członkami rodziny lub osobami z nim powiązanymi. Zazwyczaj najstarszy syn był odpowiedzialny za zakończenie budowanego przez ojca grobowca, poprowadzenie pogrzebu, a następnie za troskę o nieustający kult ojca. Tym samym kult zmarłych można porównać do codziennego kultu bogów. Zmarłym podobnie jak bóstwom, rodzina zobowiązana była do składania ofiar, posiadania figurki zmarłego w domu i do praktykowania innych przejaw kultu ${ }^{3}$. Wiara w życie pozagrobowe w starożytnym Egipcie objawiała się także poprzez uznanie, iż grób był tylko przejściem, bramą do innego świata. Jednak do zachowania prawa do życia pozagrobowego istotne było zachowanie tu na ziemi ciała człowieka w stanie prawie nienaruszonym. Dlatego zatem rozwinął się cały rytuał pogrzebowy oraz instytucja mumifikacji.

Zarazem jednak społeczeństwo egipskie opisywane było jako składające się z czterech grup: bogów, faraonów, zmarłych i żywych zobowiązanych służyć faraonowi oraz składać dary bogom i duchom zmarłych. Zmarli byli zatem związani z żywymi, a żywi ze zmarłymi. Niemniej jednak ważna była osoba zmarłego, bowiem tylko niektórzy mieli prawo do nieustającego kultu i szacunku żywych. Jedna z egipskich legend opowiada historię człowieka ubogiego, który został pochowany bez należnego mu ceremoniału i nie wybudowano mu bogatego grobu. Jednakże uznając jego zasługi na ziemi został uhonorowany miejscem obok samego Ozyrysa. Tymczasem zmarły równocześnie z nim bogacz został zwykłym odźwiernym. Powyższa opowieść wyraźnie wskazuje, iż w tradycji egipskiej los duszy człowieka nie był powiązany z jego grobowcem ${ }^{4}$. Zależny był on bowiem od osądu człowieka po jego śmierci ${ }^{5}$.

\footnotetext{
2 Por. J. Baines, M. C. Lacovara, Burial and the dead in ancient Egyptian society, "Journal of Social Archeology" vol. 2 (1): 5-36, London 2002, s. 23.

3 Por. J. Baines, M. C. Lacovara, Burial and the dead in ancient Egyptian society..., dz. cyt., s. 10-11.

4 Grobowiec jednak w ogólnym pojmowaniu miał za zadanie zapewnić jego właścicielowi przejście do następnego świata. Wiąże się to zatem z postrzeganiem grobowca jako wspólnie przynależnego do świata żywych i świata umarłych. Grobowiec bowiem przeżywał tego, który go wybudował i trwał w pamięci żywych niezależnie od losu po śmierci zmarłego w nim pochowanego. Grób pozostawał zatem odwiecznym świadkiem życia zmarłego, dowodem jego czynów za życia i trwał w pamięci żywych.

5 Por. J. Baines, M. C. Lacovara, Burial and the dead in ancient Egyptian society..., dz. cyt., s. 16-17.
} 


\section{Prawo w starożytnym Egipcie}

Kultura egipska postrzegała prawo jako dar pochodzący od boga, a imieniem bogini Maat określała ziemski porządek prawny. Teistyczna koncepcja pochodzenia prawa powiązana była ściśle z postrzeganiem faraonów jako bogów na ziemi, którzy tym samym byli źródłem i wykonawcami prawa. Odzwierciedlenie tej koncepcji znajdywało miejsce w nazwach jakimi posługiwali się urzędnicy sądowi sprawujący władzę w imieniu faraona, bowiem nosili oni tytuł kapłana Maat i przysługiwało im prawo do noszenia symbolu bogini - strusiego pióra. W praktyce prawo zatem było systemem na potrzeby którego stworzono procedury. Prawo egipskie było zatem zmienne w czasie i nie znano rozróżnienia na prawo naturalne i prawo stworzone przez człowieka.

Zgodnie z tradycją egipską prawo określano jako $h p$ - co najprościej można przetłumaczyć jako prawo, zwyczaj, obowiązek czy uprawnienie ${ }^{6}$.

Przeciwieństwem Maat była Isfet. Dlatego obowiązkiem każdego władcy było zniszczenie Isfet i zastąpienie jej Maat. Faraon oddając każdemu we władztwo ziemię zobowiązywał każdego kto ją posiadał do ustanowienia na niej Maat ${ }^{7}$.

\subsection{Umowy cywilne a śmierć człowieka}

Prawu egipskiemu znane były dwustronne kontrakty handlowe, w których dwie strony zobowiązane były świadczyć sobie wzajemnie określone zobowiązanie. Najczęściej były to pisemne umowy kupna-sprzedaży. Z tego względu, iż nic poza słowem danym przez drugą stronę nie gwarantowało w ogóle realizacji umowy ${ }^{8}$, strony umowy uzupełniały spisaną umowę o dodatkową klauzulę, która dawała jednej lub obu stroną umowy prawo do domagania się kary śmierci dla kontrahenta, który nie wywiązał się ze swoich zobowiązań umownych 9 .

Obok umów handlowych prawo cywilne egipskie znało także jeszcze jedną formę umów związanych bezpośrednio ze śmiercią człowieka - umowy na wypadek śmierci. Niestety niewiele zachowało się do dnia dzisiejszego dowodów pisanych, które umożliwiłyby głębszą analizę tego niezwykle ciekawego zagadnienia.

Podkreślić należy, iż pomimo, że kult zmarłego był niejako obowiązkiem żywych, którzy mieli za zadanie regularnie odwiedzać zmarłego, to często żywi już

6 Por. E. Cruz-Uribe, Saite and Persian demotic cattle documents, a study in legal forms and principles in ancient Egypt, Chico 1985, s. 82.

7 Por. K. Muhlestein, Violence in the service of order: the religious framework for sanctioned killing in Ancient Egypt, "BAR International Series" 2299 (2011), s. 2.

8 Bowiem nie znane były instrumenty prawnego przymusu do wykonania umowy.

9 Por. Y. Muffus, Studies in the Aramaic legal papyri from Elephantine, Boston 2003, s. 45. 
za życia podejmowali środki zapobiegawcze mające zapewnić im trwałość kultu po śmierci.

Lokalny gubernator Hapidjefai na przykład zawarł z kapłanem Asytut, w czasie wczesnej 12 dynastii kilkanaście umów na wypadek swojej śmierci. Zgodnie $\mathrm{z}$ jej treścią w czasie określonych świąt oraz uroczystości odprawiane miały być specjalne ceremonie dla uczczenia gubernatora. Kapłani zatem zobowiązani byli do celebrowania takich samych ceremonii jakie były zastrzeżone dla bogów czczonych w tej świątyni i dla zmarłego objętego umową. Gubernator miał mieć zatem zapewniony trwały nieustający kult po swojej śmierci tak długo jak długo istniała świątynia.

Z czasem takie umowy stały się powszechne i kapłani w świątyni odprawiali ceremonie dla uczenia bogów i zmarłych. Zmarli uczestniczyli zatem bardziej bezpośrednio w kulcie bogów, zmarli bowiem mediowali za żywymi u bogów ${ }^{10}$.

\section{2. Śmierć w imię prawa}

Powracając do rozważań na temat prawa faraona do dysponowania życiem ludzkim należy dokonać analizy porządku prawnego starożytnego Egiptu w kontekście kary najwyższej - kary śmierci. Utrzymanie Maat związane było ze stosowaniem przemocy, a tym samym z karą śmierci. Współczesne badania archeologiczne wykazały, iż w starożytnym Egipcie znane były zabójstwa rytualne w różnych formach, wykonywane były egzekucje więźniów, a także w czasie XVIII Dynastii istniała kara śmierci ${ }^{11}$. Za uznaniem, iż prawo egipskie przewidywało karę śmierci przemawiają również dowody archeologiczne w postaci inskrypcji na grobach, malowidłach ściennych oraz z zapisów kronikarzy.

\subsection{Zabójstwo rytualne i kara śmierci}

Oprócz rytualnego zabójstwa w czasie ceremonii religijnych znane są także przypadki rytualnego zabicia więźniów w czasie poszczególnych koronacji królewskich, jak na przykład zabicie przywódców opozycji w czasie koronacji Amenhotepa II. Dodatkowo niezmiernie popularne było rytualne zabijanie przez faraonów jeńców wojennych. Było to niejako prawo faraona i demonstracja jego siły i potęgi. Ciała zabitych (osobiście przez faraona) jeńców wojennych były następnie transportowane rzeką Nil w uroczystej procesji na łodzi, którą płynął także i sam

\footnotetext{
${ }^{10}$ Por. Y. Muffus, Studies in the Aramaic legal papyri from Elephantine..., dz. cyt., s. 22.

${ }^{11}$ Por. K. Muhlestein, Violence in the service of order..., dz. cyt., s. 20-40.
} 
faraon, następnie były umieszczane w świątyniach, jako swoisty trybut władcy dla bogów za okazaną mu pomoc ${ }^{12}$.

Opisane w ten sposób zabójstwa dotyczą prawa wojennego - prawa władcy do zabicia wroga - jeńca wojennego. Czy jednak prawo egipskie dopuszczało skazanie własnego obywatela na karę śmierci?

Najważniejszym argumentem, przemawiającym za istnieniem w starożytnym Egipcie kary śmierci jest historia kobiety zwanej Heria oskarżonej o kradzież miedzianych dłut ze świątyni w Amun. Początkowo kobieta złożyła przysięgę, iż nie dokonała kradzieży jednakże dokonane przeszukanie w jej domu uwodniło nieprawdę jej przysięgi. Została ona zatem obwołana „wartą śmierci”. Zachowane zapiski wezyra kończą historię w tym miejscu. Niemniej jednak Ostracon Nash I przywołuje sprawę Herii wskazując, iż została ona odesłana do dna rzeki (utopiona). Powyższe przemawia jednoznacznie za uznaniem, iż Heria została stracona za kradzież dłut ${ }^{13}$.

Podkreślić należy, iż ostateczne słowo w przedmiocie kary śmierci należało zawsze do faraona lub wezyra. Sąd wioskowy nie mógł samodzielnie podjąć decyzji w przedmiocie skazania Herii za kradzież mienia należącego do boga Amon. Uznając ją winną za popełniony czyn, oddali ją do dyspozycji wezyra, który działał $\mathrm{z}$ upoważnienia faraona $\mathrm{i} w$ jego imienu ${ }^{14}$.

Znana jest także treść edyktu Horemheba, w którym król ostrzega, iż w przypadku gdy przestępstwo jest poważne grozi za nie kara śmierci. W przypadku gdy sędziowie zaniechają orzeczenia kary śmierci powinni zostać uznani za przekupionych. Tekst jest jednak niepełny i w sposób niebudzący wątpliwości nie można orzec jakie rodzaje przestępstw zostały uznane za warte śmierci. Również inskrypcje nagrobne na grobie Amenhotepa przedstawiają zapisy grożące karą śmierci poprzez spalenie tym, którzy dokonaliby zbeszczeszczania grobu oraz przyległej do niego kaplicy.

W późniejszym okresie kara śmierci groziła także tym, którzy życzyli śmierci lub złorzeczyli faraonowi lub jego żonie. Również wygłaszanie negatywnych opinii o rodzinie panującej zagrożone było karą śmierci. Przykładem takiej regulacji prawnej jest edykt Thutmosisa I, zgodnie z którym: „każdy kto będzie mówił diabelskie (złe) rzeczy na drodze królowej (Hatshepsut DEir el-Bahrin) powinien umrzeć"15.

\footnotetext{
${ }^{12}$ Por. K. Muhlestein, Violence in the service of order..., dz. cyt., s. 46-47.

${ }^{13}$ Por. K. Muhlestein, Violence in the service of order..., dz. cyt., s. 48-49.

${ }^{14}$ Por. E. D. Bedell, Criminal law in the Egyptian Ramesside period, London 1973, s. 149.

15 E. D. Bedell, Criminal law in the Egyptian Ramesside period..., dz. cyt., s. 50-51.
} 
Podejście do kary śmierci jako sposobu karania za poważne przestępstwa została w pełni sformalizowana za czasów Ramzesa oraz nazwanej od jego imienia dynastii faraonów. Z tego czasu zachowało się także najwięcej tekstów pisanych i jurydycznych, które umożliwiają dokonanie pełnej analizy interesującego nas zagadnienia śmierci w prawie egipskim.

Istotne jest także uświadomienie sobie, iż w tym okresie zmieniło się także rozumienie prawa, faraon coraz rzadziej by postrzegany jako bóstwo lub pośrednik boga, upadał także jego autorytet jako władcy i najważniejszej osoby w państwie. Niemniej jednak Ramzes I przywrócił faraonom należny im szacunek jako władcom, ale już nie jako bóstwom. Dlatego także prawo do wymierzania kary śmierci zostało ograniczone. Przestępstwem zagrożonym karą śmierci było zatem nastawanie na życie faraona lub kradzież własności bogów. Fraza użyta w treści aktu prawnego to „przestępstwo warte śmierci”. W tej kategorii zawarte także było zbezczeszczenie grobowców oraz rabunek grobowców. Zachowało się kilka tekstów, z treści których wynika, iż sprawcy wiedzieli, iż za dokonanie rabunku grobów zostaną pozbawieni życia. Ellen Bedell w swojej książce Criminal law in the Ramesside period przytacza dwie historie Amenkhauka i Thewenani, którzy zostali oskarżeni o rabunek grobów. Historia Amenkhau została opowiedziana w formie dialogu pomiędzy nim a jego przeciwnikiem Perpethew. Amenkhau twierdząc bowiem, iż został niesłusznie oskarżony przez Perpethew o rabunek grobów. Perpethew bronił się bowiem przed sądem, mówiąc, iż w sytuacji gdy zostanie on skazany za rabunek na karę śmieci to zabierze ze sobą Amenkhau. Amenkahau z kolej bronił się mówiąc: „kłóciliśmy się i ja powiedziałem do niego zostaniesz skazany na śmierć, za kradzież w Necropolis. On mi odpowiedział: Jeżeli ja pójdę zabiorę Ciebie ze sobą"16. Podobnie została ukazana historia cieśli Thewenani, który przesłuchującym go w sprawie rabunku grobów powiedział: „Widziałam na jaką karę zostali skazani złodzieje za taki czyn w czasach wezyra Khaemwese. Czy zatem sam bym szukał śmierci?”17. Odnalezione manuskrypty egipskie przytaczają jeszcze wiele takich historii, z których wynika, iż każdemu kto dopuścił się przestępstwa rabunku grobowców, czy to faraonów czy innych zwykłych ludzi groziła kara śmierci. Przekonał się o tym niewolnik kupca Pesienwesa, który broniąc się przed zarzutem okradzenia Wielkich Grobowców ${ }^{18}$, przyznał się do kradzieży mniejszej wagi w grobowcach Iumiteru. Pomimo tego i tak został skazany na karę śmierci. Zachowały się także teksty, z których wynika, iż skazanemu przysługiwało prawo odwołania się od decyzji sądu do instancji ostatecznej, to jest do samego

\footnotetext{
${ }^{16}$ Cyt. za: E. D. Bedell, Criminal law in the Egyptian Ramesside period..., dz. cyt., s. 145-146.

17 E. D. Bedell, Criminal law in the Egyptian Ramesside period..., dz. cyt.

${ }^{18}$ Grobowców przynależnych rodzinie faraonów i ich dworowi.
} 
faraona. Taka sytuacja miała miejsce w sprawie Amenpnefera i jego wspólników, którzy zostali skazani za zbezczeszczenie grobu króla Sekhemre-shedtaui - Syna Re, Sebkemsaf i jego doradców oraz królowej Nubkhaas. W oczekiwaniu na decyzję faraona zostali oni umieszczenie w więzieniu w domu Amon-Re ${ }^{19}$.

Karą śmierci zagrożona była także wszelka kradzież mienia należącego lub mogącego należeć do samego faraona. W posiadaniu British Museum znajduje się Ostracon nr 5631 który opowiada historię trzech służących posłanych po dwa dzbany pełne miedzianych przedmiotów. Na miejscu okazało się, iż istnieją dwa dzbany zawierające miedziane elementy oraz trzeci, który zawiera oprócz miedzianych także złote przedmioty. Mężczyźni nie zdecydowali się na zabranie dla siebie trzeciego dzbana w obawie, iż zostaną skazani na śmierć za kradzież mienia faraonów ${ }^{20}$.

Prawo egipskie z czasów dynastii Ramzesów zna jeszcze przypadki innych czynów zagrożonych karą śmierci. Wymienia je choćby edykt wydany dla ochrony mienia posiadanego przez Ozyrysa przez Nauri Decree. Na karę śmierci miał zostać skazany każdy komu oddano w opiekę zwierzęta należące do Ozyrysa, a on zamiast otoczyć je należytą opieką w jakikolwiek sposób utracił je lub przeznaczył na ofiarę innemu bogowi. Taki czyn traktowany był jako świętokradczy i zdradziecki, jedyną karą jaka zatem mogła spotkać sprawcę była śmierć. Innym przestępstwem zagrożonym karą śmierci było spiskowanie na życie faraona, zdrada stanu, działanie na niekorzyść państwa oraz przekupstwo urzędników. Prawo do wydania wyroku skazującego na śmierć $\mathrm{w}$ tym przypadku było scedowane $\mathrm{z}$ faraona na sąd i nie przysługiwało już oskarżonym prawo do odwoływania się do woli faraona. Wydaje się, iż w takich przypadkach przekroczenie norm społecznych było tak oczywiste, iż ustawodawca egipski nie widział potrzeby ponownego badania sprawy.

Karę śmierci za korupcję przewidywał na przykład Edykt Haremhaba zgodnie z którym każdy sędzia, który sprzeniewierzył się swojemu urzędowi sędziowskiemu powinien zostać skazany na karę śmierci. Również wszyscy spiskujący przeciwko życiu faraona Ramzesa III zostali skazani na śmierć. Podkreślenia wymaga także fakt, iż sędziowie ponosili bezpośrednio odpowiedzialność za wydany wyrok i wyrok ich wiązał i jeżeli był niesprawiedliwy obciążał ich sumienie ${ }^{21}$.

\footnotetext{
19 Por. E. D. Bedell, Criminal law in the Egyptian Ramesside period..., dz. cyt., s. 147-148.

${ }^{20}$ Por. E. D. Bedell, Criminal law in the Egyptian Ramesside period..., dz. cyt., s. 151.

${ }^{21}$ Por. E. D. Bedell, Criminal law in the Egyptian Ramesside period..., dz. cyt., s. 152-153.
} 


\subsection{Formy śmierci}

Egipska kultura znała także różne formy odebrania życia człowiekowi, czy to poprzez spalenie, nabicie na pal, utopienie oraz przeróżne inne trudne do wyobrażenia formy. Niemiej jednak w literaturze przedmiotu istnieje zgoda co do tego, iż podstawową formą wymierzania kary śmierci była dekapitacja. Kwestią domniemania pozostaje natomiast sprawa wrzucenia do studni czy utopienia. Zachowane teksty można bowiem interpretować w różny, odmienny sposób, albo jako śmierć głodową w studni, albo jako utopienie. Pozostałe zatem formy, takie jak wbicie na pal czy utopienie, są wyłącznie kwestią interpretacji różnych zapisów i fresków. Brak jest jednoznacznego dowodu, iż te dwie metody były wykorzystywane w Egipcie jako formy legalnej egzekucji ${ }^{22}$.

Formą dozwolonej egzekucji było także rozszarpanie przez krokodyle lub spalenie. Powyższe jest o tyle istotne, iż według egipskiej tradycji jednym z najważniejszych elementów było zachowanie ciała po śmierci. Zatem w przypadku zjedzenia przez krokodyle lub spalenia, sprawca nie mógł dostąpić życia po śmierci. Z drugiej jednak strony ogień i woda były postrzegane jako element oczyszczający, pozwalający narodzić się na nowo. Różnica polegała na tym, iż zmarły który przeszedł drogę wody i ognia nie był przez nie skonsumowany, zaś skazaniec i jego ciało ulegało zagładzie całkowitej ${ }^{23}$.

\subsection{Samobójstwo}

Ostatnią dozwoloną prawnie formą zabicia człowieka było przymusowe samobójstwo. Postrzegane było jako łagodniejszy wymiar kary i przysługiwało przede wszystkim urzędnikom wyższej rangi, którzy zostali skazani na karę śmierci. Przykładem takiego orzeczenia jest sprawa spisku w haremie za czasów Ramzesa III. W tej konkretnej sprawie faraon osobiście poinstruował sędziów, iż jeżeli wydadzą wyrok skazujący na karę śmierci, to ma być on wykonany w drodze przymusowego samobójstwa. Przedmiotowa sprawa jest o tyle ważna, iż pokazuje, że na karę śmierci skazywani byli nie tylko ubodzy wieśniacy, ale także wysoko urodzeni, a nawet książęcej krwi. Jednym z oskarżonych i skazanych na karę śmierci był bowiem książę Pentawer. Został on uznany winnym popełnionego przestępstwa i skazany na karę śmierci, i pozwolono mu popełnić samobójstwo ${ }^{24}$. Samobójstwo było dozwolone wyłącznie za przyzwoleniem sądu i traktowane było

\footnotetext{
${ }^{22}$ Por. E. D. Bedell, Criminal law in the Egyptian Ramesside period..., dz. cyt., s. 153-159.

${ }^{23}$ Por. E. D. Bedell, Criminal law in the Egyptian Ramesside period..., dz. cyt., s. 165.

${ }^{24}$ Por. E. D. Bedell, Criminal law in the Egyptian Ramesside period..., dz. cyt., s. 167-168.
} 
jako przywilej, samobójstwo bez zgody sądu było traktowane jako obejście prawa. $\mathrm{W}$ omawianej sprawie spisku $\mathrm{w}$ haremie, jednemu $\mathrm{z}$ oskarżonych nie przyznano prawa do samobójstwa. Jednak niezależnie od woli sędziów odebrał sobie życie i gdy jego strażnik się o tym dowiedział także zakończył swoje życie ${ }^{25}$.

\section{3. Śmierć człowieka według prawa żydowskiego}

Drogi państwa Izraela i Egiptu skrzyżowały się w czasach Józefa, wtedy to naród żydowski dobrowolnie udał się do Egiptu i poddał prawu egipskiemu, zachowując swoją tradycję i kulturę prawną. Podkreślić należy, iż prawo żydowskie wywodzi się Pięcioksięgu Mojżeszowego ${ }^{26}$. Mojżesz jako ten, który wyprowadził naród żydowski z ziemi Egipskiej był wychowany i wykształcony właśnie w Egipcie, pamiętać bowiem należy, iż był on przybranym synem Termutis, córki faraona. Mając wiedzę w przedmiocie prawa egipskiego Mojżesz za natchnieniem Bożym rozpoczął tworzenie dzisiejszego prawa żydowskiego. Bóg przekazał Mojżeszowi zbiór praw na górze Synaj. Pięcioksiąg Mojżesza zawiera zatem zbiór praw ustnej i pisanej tradycji żydowskiej. Prawo żydowskie pochodzi zatem od samego Boga i jest ono starsze niż sama ziemia. Zgodnie z tradycją żydowską słowo mishpat określa sprawiedliwość i było bardzo często używane w wyrokach wydawanych przez sądy żydowskie. Jest to termin prawny, mający podkreślić sprawiedliwość wyroku oraz jego usankcjonowanie przez Boga. Pierwotnej prawnej tradycji żydowskiej nie obce było zatem prawo talionu, wyrażone najbardziej dobitnie w Księdze Wyjścia (Wyj 21, 24) w słynnej do dnia dzisiejszego zasadzie prawa: „oko za oko, ząb za ząb, ręka za rękę, noga za nogę”. Prawo Boże wprowadza zatem zasadę, iż każdy powinien ponosić odpowiedzialność za swoje czyny, każdemu kto dobrze czyni będzie odpłacone dobrem, temu co źle czyni będzie odpłacone złem. Prawo żydowskie ma bowiem swoje korzenie w kodeksie Hamurabiego, który kładzie duży nacisk na zemstę i zasadę restytucji ${ }^{27}$. Przedmiotowe zasady obowiązywały w społeczności żydowskiej do czasu wprowadzenia wspomnianego powyżej Prawa Mojżeszowego. Zmiany prawa powiązane były ściśle ze zmianą trybu życia, będąc do tej pory społeczeństwem osiadłym, po wyjściu z niewoli Egipskiej, Żydzi przyjmują osiadły tryb życia i adaptują prawo kananejskie.

\footnotetext{
${ }^{25}$ Por. E. D. Bedell, Criminal law in the Egyptian Ramesside period..., dz. cyt., s. 169.

${ }^{26}$ Por. J. G. Griffiths, The divine verdict, a study of divine judgment in the ancient religions, New York 1991, S. 10.

${ }^{27}$ Por. J. G. Griffiths, The divine verdict..., dz. cyt., s. 12-15.
} 
Mojżesz wprowadził zatem społeczności żydowskiej zinstytucjonalizowane sądownictwo (Wyj 18, 13). Zgodnie z Księgą Wyjścia godni zaufania mężowie zostali wybrani na sędziów i powierzono im władzę nad całym społeczeństwem. Sędziowie zasiadają w zgromadzeniach liczących tysiąc, stu, pięćdziesięciu i dziesięciu. Po wprowadzeniu monarchii król żydowski stał się ostatnią instancją odwoławczą od orzeczeń sądów żydowskich. Najwyższą instancją ponad wszystkimi sądami był zaś Jahwe. Sądy obradowały głównie w miastach, na otwartej przestrzeni przy bramach miasta i zasiadało w nich około 7 do 23 sędziów. W sprawach znacznej wagi właściwy był Sanhedryn w Jerozolimie. Od decyzji sądów lokalnych także przysługiwało prawo do odwołania się do Sanhedrynu. Każda sprawa aby mogła pojawić się przed sądem żydowskim musiała być poparta zeznaniami co najmniej dwóch świadków: wolnych dorosłych mężczyzn ${ }^{28}$.

W świetle niniejszej publikacji pojawia się zatem pytanie czy prawo żydowskie przewidywało karę śmierci. W myśl tradycji żydowskiej Bóg dając prawo Mojżeszowi na górze Synaj wyznaczył także granice życia ludzkiego. Prawo i tradycja żydowska w przeciwieństwie do Egipskiej ukierunkowana była na życie i wiarę w życie doczesne. Mojżesz położył także duży nacisk na wartość życia i pokojową koegzystencję różnych grup społecznych i narodów ${ }^{29}$.

Prawo żydowskie wprowadzone przez Mojżesza przesądzało zatem o świętości życia ludzkiego niezależnie od jego stanu i pochodzenia. Każda istota ludzka miała zatem prawo do życia i prawo do naturalnej śmierci. Czy zatem prawo żydowskie dopuszczało karę śmierci? Odpowiedź na to pytanie jest twierdząca. Już w Księdze Rodzaju, można zauważyć przyzwolenie na stosowanie kary śmierci. Bóg mówi bowiem: „kto rozlewa krew człowieka tego krew będzie rozlana przez człowieka". Bóg zatem przekazał swoje prawo do karania człowieka śmiercią za morderstwo na innym człowieku. Człowiek jest bowiem stworzony na obraz i podobieństwo Boże. To porównanie pozwala nam stwierdzić zatem, iż życie ludzkie wedle Żydów jest cenne i każdy, kto zabiera życie człowiekowi nie zasługuje na to, by swoje życie zachować. Każde życie ludzkie warte było ochrony niezależnie od statusu społecznego tego kto życie stracił. Zarazem jednak Pięcioksiąg Mojżesza rozróżnia śmierć zadaną przypadkowo od śmierci zamierzonej - morderstwa ${ }^{30}$.

Prawo Mojżeszowe nakazywało zatem stosowanie kary śmierci w przypadku umyślnego pozbawienia człowieka życia, zabraniało stosowania innej kary lub przyjmowania wynagrodzenia pieniężnego. Zgodnie z Księgą Liczb $(35,31)$ pobożny Żyd nie może przyjąć żadnego okupu za życie zabójcy, który jest winien śmierci.

\footnotetext{
${ }^{28}$ Por. J. G. Griffiths, The divine verdict..., dz. cyt., s. 15-16.

${ }^{29}$ Por. T. Chandler, Moses \& the Golden Age, Dorrance 1986, s. 6, 45.

${ }^{30}$ Por. J. G. Griffiths, The divine verdict..., dz. cyt., s. 15-16.
} 
Morderca nie miał także prawa wstępu do świątyni i nie mógł szukać w niej schronienia (Wj 21, 14). Prawo talionu znalazło zatem całe swoje odbicie w zasadach prawa żydowskiego w stosunku do kary śmierci. Niemiej jednak na karę śmierci mógł winnego skazać wyłącznie Sanhedryn podejmując decyzję przewagą głosów, ale nie jednomyślnie. Gdy wyrok zapadał jednomyślnie nie był wykonywany. Skazany na karę śmierci mógł oczekiwać zatem, iż zostanie ona wykonana poprzez ścięcie mieczem, uduszenie, ukamienowanie lub spalenie. Powszechnym sposobem wykonywania kary śmierci było uduszenie, pozostałe formy były zastrzeżone dla określonych rodzajów przestępstw. Przestępstwa, za które Pięcioksiąg Mojżesza przewidywał karę śmierci, podobnie jak w Egipcie, związane było z oddawaniem czci innym bogom, bałwochwalstwo, wspomniane już morderstwo, kazirodztwo czy cudzołóstwo.

Podsumowując powyższe rozważania uznać należy, iż prawo izraelskie uznawało karę śmierci za wyjątkową i należną za wyjątkowe przewinienia. Sanhedryn niezwykle rzadko podejmował decyzję w przedmiocie skazania na karę śmierci, która była wykonywana zazwyczaj przez uduszenie lub ukamienowanie. Żydzi uznawali zatem za swój obowiązek skazać na karę śmierci tego, kto pozbawił życia drugiego człowieka, tego kto naruszył prawo Boże. Pozostawienie przy życiu tego, kto zabił lub czcił innego boga było uznawane za niedopuszczalną niesprawiedliwość dziejową.

\section{Porównanie}

Porównując zatem obie kultury prawne, egipską i żydowską nie można nie zauważyć, iż znacznie różniły się one od siebie w zakresie podejścia do człowieka i wiary w życie pozagrobowe oraz samym postrzeganiem śmierci. Człowiek w Egipcie żył dla zmarłych, troszczył o się o zmarłych oraz o swoje życie po śmierci. Kara śmierci była zatem najwyższą z możliwych kar gdyż w większości przypadków pozbawiała skazanego życia po śmierci, jego ciało bowiem ulegało zniszczeniu. Wykonanie kary śmierci poprzez dekapitację lub spalenie unicestwiało człowieka na zawsze. Dlatego też kara ta była wymierzana w ostateczności i to przez najwyższe organy państwowe z prawem odwołania się od decyzji sądu do samego faraona. Innego rodzaju prawa miały zastosowanie do jeńców wojennych, którzy prawie zawsze byli skazywani na śmierć i ich ciała były traktowane jako dowód chwały faraona.

Tymczasem społeczność żydowska uznawała za najważniejsze życie na ziemi, zatem odebranie życia innemu człowiekowi było najwyższym z możliwych przestępstw, bowiem naruszało równowagę świata. Żydzi zatem dążyli przede 
wszystkim do zachowania życia człowieka, ale śmierć nie była także końcem. W przeciwieństwie do Egipcjan, dla Żydów nieistotny był los ciała po śmierci, dlatego samo wykonanie kary śmierci nie pozbawiało człowieka prawa do życia po śmierci i nie unicestwiało go w całości.

Obie kultury znały i praktykowały karę śmierci, choć różne były przestępstwa zagrożone tą karą i różna była także waga samej śmierci.

\section{Proponowana literatura}

Baines J., Lacovara M. C., Burial and the dead in ancient Egyptian society, „Journal of Social Arcgeology" vol. 2 (1), London 2002, s. 5-36.

Bedell E. D., Criminal law in the Egyptian Ramesside period, London 1973.

Chandler T., Moses \& the Golden Age, Dorrance 1986.

Cruz-Uribe E., Saite and Persian demotic cattle documents, a study in legal forms and principles in ancient Egypt, Chico 1985.

Griffiths J.G., The Divine Verdict, a study of divine judgement in the Ancient Religions, Leiden, New York 1991.

Muffus Y., Studies in the Aramaic legal papyri from Elephantine, Boston 2003.

Muhlestein K., Violence in the service of order: the religious framework for sanctioned killing in Ancient Egypt, „BAR International Series” 2299 (2011). 